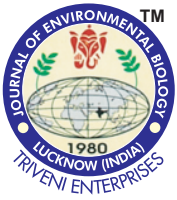

\title{
Application of Soil Water Assessment Tool (SWAT) to suppress wildfire at Bayam Forest, Turkey
}

\section{Authors Info}

M. Tufekcioglu ${ }^{1 *}$ M. Yavuz ${ }^{1}$ G. N. Zaimes', M. Dinc', P. Koutalakis ${ }^{2}$ and A. Tufekcioglu

${ }^{1}$ Faculty of Forestry, Artvin Coruh University, Seyitler-08000, Artvin, Turkey

${ }^{2}$ Department of Forestry and Natural Environment Management, Eastern Macedonia and Thrace Institute of Technology

(EMaTTech), Drama-Mikrohoriou, Drama-66100, Greece

*Corresponding Author Email : mtufekcioglu61@artvin.edu.tr

\section{Key words}

ArcSWAT model, Digital elevation model, Fire management, Hydrological modeling, Wildfire suppression

\section{Publication Info}

Paper received : 08.06.2016

Revised received : 05.12 .2016

Re-revised received : 15.02 .2017

Accepted: 09.03.2017

\section{Abstract}

Aim: Readily available water resources are a key for wildfire suppression. Hydrologic models are a practical and essential tool for understanding the processes of hydrology and managing water resources, but have not been utilized as frequently for wildfire suppression. The goal of the present study was to use the Soil Water Assessment Tools (SWAT) model to determine whether the stream water could be managed sustainably in wildfire suppression at the Bayam Forest District in Kastamonu Province, Turkey.

Methodology: As an input file, the SWAT model used soils, land-uses, weather data and morphology of watershed based on the Digital Elevation Model (DEM). The model was applied for period 2001-2013 in order to predict the water budget of the study area and major streams within the studied district.

Results: The analysis of the hydrologic water budget indicated that $70 \%(573.8 \mathrm{~mm})$ of $\mathrm{the}$ a n n u a I precipitation $(822$ $\mathrm{mm}$ ) was lost as evapotranspiration in the basin, whereas $19 \%, 34 \%$ and $47 \%$ of the remaining total water yield $(234.6$ $\mathrm{mm}$ ) contributed to streams via surface runoff, groundwater flow and lateral flow, respectively.

Interpretation: Overall, the result of SWAT model indicated to a certain degree promising findings on the availability of stream water and optimal placement of water reservoir for the use of wildfire suppression.

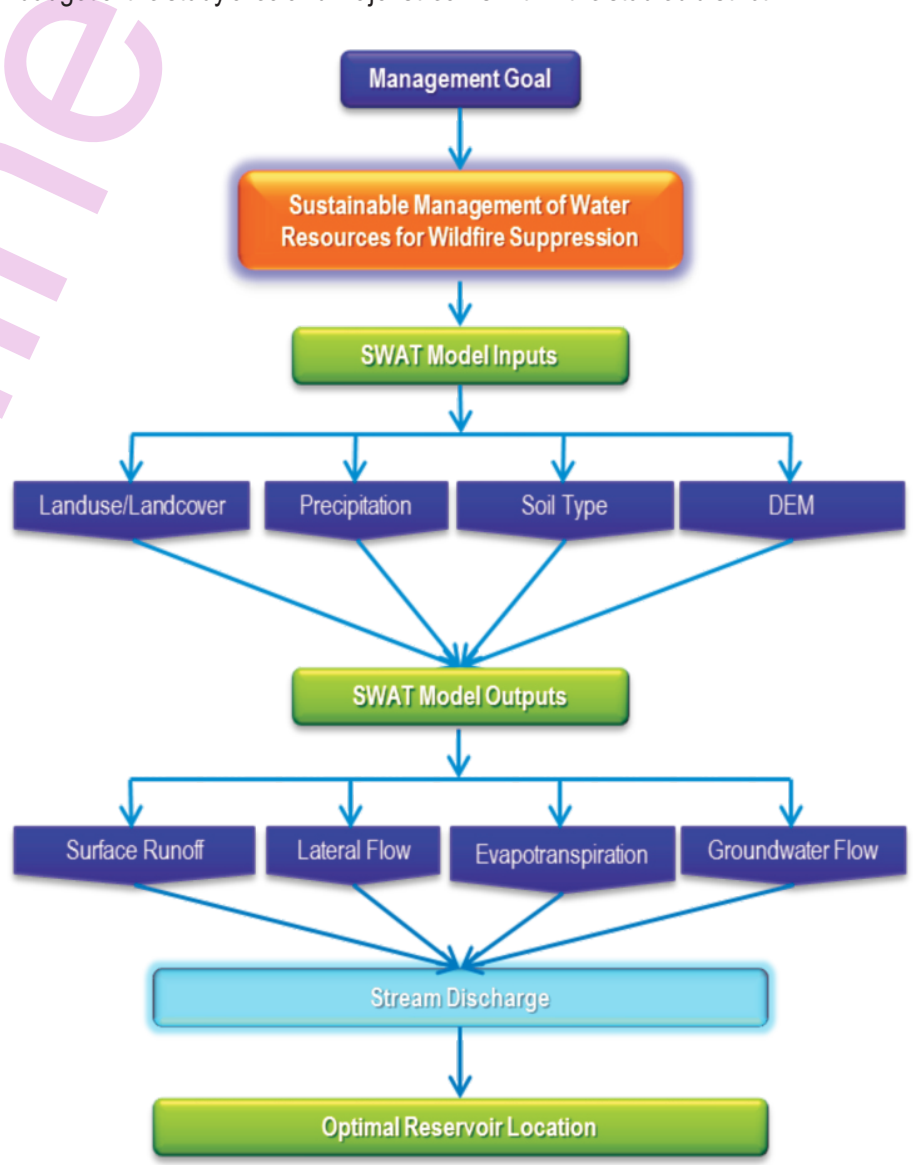




\section{Introduction}

Forest wildfires pose an increasing threat to the environment due to imposing climate change and associated global warming that would increase the size of burnt area in the future and their potential impact on ecosystem services, as well as release of carbon in atmosphere (Amiro et al., 2001). The increase in large wildfires is significantly related to the number of days with high temperature (Cardil et al., 2014). Dalfes et al. (2007) reported widespread increase in summer temperature, mostly in the western and southwestern parts of Turkey, where most of the high wildfire risk areas are located (Ozturk et al., 2010), while winter temperature have shown a decreasing trend. About $57 \%$ (12.5 million ha) of the total forest area in Turkey is considered as sensitive to wildfire-risk (first and second degree fire sensitivity level) (GDF-DFFF, 2014). Approximately 7 million people live in villages that are located either within the forest or adjacent to the forest. More than half of these people are either directly or indirectly affected by the forest wildfires. Recorded data from 1988 to 2012 show that the average amount of burnt area in Turkish forests was 11.236 ha per year and the average number of forest wildfires was 2003 per year (MFWA, 2012). The average annual budget for forest wildfire suppression from 2005 to 2014 was 43.7 million Turkish Lira (TRY) (in December 2005: \$ = 1.34 TRY, in December 2014: \$= 2.31 TRY) (GDF-DFFF, 2014). When including the damages such as loss in the timber production and expenses spent in the afforestation efforts after the wildfire, the total budget spent during 2014 was 63.1 million TRY.

Forest wildfires continue to remain as one of the most serious disasters worldwide, despite the recent substantial investments in technology in the forestry sector employed for wildfire prevention and suppression. Forest wildfires can affect both human health, and functioning of a forest ecosystem including changes in soil properties, biomass and nutrient dynamics (Tufekcioglu et al., 2010a, b; Yildiz et al., 2010) and associated wild fauna (Lyon et al., 2000), improper functioning of the ecosystem component (Neary et al., 2005), increase in greenhouse gas emission (Amiro et al., 2001), and deterioration in soil quality due to increasing surface soil erosion (Robichaud, 2000). The environmental and socio-economic impact of forest wildfires can be reduced by integrated forest wildfire management strategies that include an increase in public awareness and interactions among the stakeholders (BrenkertSmith, 2010), active wildfire prevention management mainly in the form of large scale fuel management and fuel-reduction techniques along with increased suppression efforts (Fernandes, 2013; Meddour-Sahar, 2014), and use of innovative technique and technologies by all the governmental partners and/or private research developers to enhance current suppression efforts (BCWS, 2010). Many efforts and progress in improving wildfire awareness and fuel management methods have been made in the last decade, but there are still improvements that can be made specifically by integrating innovative techniques and technologies to cope with the forest wildfire at larger scales (Zaimes et al., 2014). It has been stated that the most effective and efficient way to control large wildfire is to extinguish it as soon as possible, before it gets out of control (Rachaniotis and Pappis, 2011). Being quick and reactive during the initial attack is only possible when readily-available and sufficient water resources and infrastructures are closely situated at the potential wildfire site. These are priorities in many wildfire prone countries including Turkey. The prerequisites for achieving these are proper location of the infrastructures like water ponds, forest roads, fuel breaks, lookout towers and sustainable management of water resources by innovative techniques and technologies.

To accomplish this, physically-based modeling tools (SWAT, WEPP etc.) can be used to predict the discharge of streams, as well as identifying potential stream networks with the available water resources (Arnold et al., 1998; Nearing et al., 1989). In the present study, the Soil and Water Assessment Tool (SWAT) was used to predict potential streamflow. It is a public domain model developed by the USDA Agricultural Research Service (USDA-ARS) and Texas A\&M AgriLife Research (Arnold et al., 1998). The SWAT is widely used in regional watershed management to reduce soil erosion and non-point source pollution in watersheds (Gassman et al., 2007). With a variety of physical and chemical models, SWAT can simulate runoff, evaporation, groundwater, rainfall and other hydrological processes (Neitsch et al., 2005).

The aim of the present research was to utilize SWAT as a new innovative technique to identify the most suitable locations for water reservoirs to suppress wildfires in Turkish forests. To our knowledge this is the first attempt to conduct this study in Turkey.

\section{Materials and Methods}

Study area: The study area included the Bayam Forest District that lies between $41^{\circ} 27^{\prime} 24^{\prime \prime} \mathrm{N}$ and $41^{\circ} 35^{\prime} 11^{\prime \prime} \mathrm{N}$ longitudes $34^{\circ}$ $13^{\prime} 12^{\prime \prime} E$ and $34^{\circ} 26^{\prime} 30^{\prime \prime} E$. It covers an area of about $160 \mathrm{~km}^{2}$ and is located in Kastamonu Province in North Central Turkey (Fig. 1). The terrain is hilly, and the elevation ranges between $480 \mathrm{~m}$ to $1500 \mathrm{~m}$ above msl. Eighty percent of the region is covered by forest, while the remaining $20 \%$ is used for agricultural and residential purposes. The mean annual precipitation in Kastamonu is $489 \mathrm{~mm}$. During the period 1962-2014, 53 wildfire incidents were recorded in the area that burnt 509 ha of forested land (GDF, 2009). Of the total area burnt, 110.6 ha land was burnt during the last ten years (2005 to 2014). The area falls in the second degree of wildfire sensitivity according to fire threat classes of the Turkish Forest Service. Most of these wildfires were caused due to human. Four main perennial streams were run throughout the district, thus indicating that adequate water resources for wildfire suppression should be available (Fig. 1).

SWAT model: SWAT can be managed within the Geographic Information Systems (GIS) through the interface named 
ArcSWAT (Winchell et al., 2013). The interface requires information about the morphology of the watershed based on the Digital Elevation Model (DEM), soils, land-use and weather data. The water budget equation that SWAT uses is as follows:

$$
\mathrm{SWt}=\mathrm{SWo}+\sum_{\mathrm{i}=1}^{\mathrm{t}}(\mathrm{Ri}+\mathrm{Qi}+\mathrm{ETi}+\mathrm{Wi}+\mathrm{Gi})
$$

where, $t$ is the simulation period, $S W_{t}$ is the soil water content after simulation period, $S W_{0}$ is the soil water content at the beginning of the simulation period, and $R_{i}, Q_{i}, E T_{i}, W_{i}$ and $G_{i}$ are daily values for precipitation, runoff, evapotranspiration, percolation and return flow from the soil profile (Neitsch et al., 2011). The configuration of SWAT uses field elevation and optional flow data to identify subbasins within their respective basins. Sub-basins are spatially distributed, and streamflow and associated contaminants are routed from one sub-basin to another. The hydrologic portion of SWAT requires identification of major streams for the prediction of water budget and stream discharge but also field measurements of discharge in order to calibrate the estimated results produced by the model.

In the SWAT configuration, the availability of daily temperature records suggested the use of the Hargreaves method to estimate evapotranspiration (Cao et al., 2006). The run-off curve number method was employed to estimate surface runoff from precipitation and the variable storage method was used to simulate channel water routing. Finally, the simulation period was from 01 January 2001 to 31 December 2013.

Spatial data and maps: All the data used in ArcSWAT for this study were from the European Datum 1950 in UTM Zone 36N. A high resolution DEM of $5 \times 5 \mathrm{~m}$ was used in ArcSWAT. The threshold value was set to 50 ha in order to create many subwatersheds for a detailed evaluation of Bayam Forest. This process divided the study area to in 134 sub-watersheds/outlets. The hydrologic response units (HRU) are unique combination of land use, soil and slope class in each sub-watershed (Neitsch et al., 2011). The HRU analysis requires maps of the land-use, soil and slope of the study area. This process created $3605 \mathrm{HRU}$ s that enhanced even more accuracy. The Corine 2006 vector files were used to define the land use map of Bayam Forest District. This land-use map was reclassified into land-cover categories that SWAT had already in its database (Fig. 2). The soil map of the Bayam Forest District was based on the soil data base of the General Directorate of Agricultural Reforms (TGHB, 2014), and it was combined with the soil map of the Harmonized World Soil Database (HWSD, 2012) that provided the physico-chemical parameters of the soils (Fig. 3). The slope categories were classified based on the statistics of DEM. The slope classes used in this study were $0-10,11-20,21-30,31-50$ and $51-311$.

Weather data: The weather data for the study area were acquired from the National Weather Department in Ankara (Station ID: 17074). The monthly values of precipitation, maximum/minimum temperature, relative humidity, wind speed and solar radiation were used to generate the time series. Also, daily data of precipitation, maximum/minimum temperatures and solar radiation from this weather station were used. The daily data covered the period from 01 January 2001 to 31 December 2013, which was also the selected time period for simulation with the SWAT model.

Stream flow measurement: The measurement of stream flow was conducted at three stations located on the major stream within the sub-watershed of study area (Fig. 1). Based on their elevation differences, these three stations were defined as lower station (station_1), middle station (station_2) and upper station (station_3) (Fig. 1). At each station, a total of 21 discharge measurements were conducted from February to November, 2014. Streamflow was measured with an electronic flow-meter (PVM-PD flow-meter). The field measurements on the selected sub-watershed/stream were used for the calibration and validation process of the model. In addition, the weather data of 2014 from Kastamonu station (from January to end of October) was used for the calibration and validation purpose.

\section{Results and Discussion}

The use of the SWAT model in assessing the water budget has proved to be a suitable tool (Gassman et al., 2007), but its application for water resources in the use of wildfire suppression has not been implemented. However, due to uncertainty in many water budget parameters, the calibration of the SWAT models is a continuing challenge (Shen et al., 2012). In the present study, the observed discharge data from major stream in the study area were used to obtain a desirable calibration for the model, but correlation between the simulated and observed discharge data set was very low and unsatisfactory to use. Many simulations were tried by changing the most sensitive parameters manually but they also produced unsatisfactory results in the calibration. An automated calibration was also tried in the SWATCUP software (Abbaspour et al., 2007). The simulated results still showed incompatibility among the recorded precipitation, the observed discharge and the simulated discharge from the model (Fig. 4). However, there seems to be some similar patterns in the values of precipitation and observed discharge from February to July. After July, the peak rainfall did not generate an increase in observed discharge (Fig. 4). It seems that the summer rainfall events were more local, while winter rains covered a larger region, that is why the weather station provided better data for winter period. Similarly, Nyeko (2015) recorded unrepresentative rainfall data to simulate peak flow due to localized storm events. In addition, daily precipitation data were acquired from NEXRAD, which is a network of high resolution Doppler radars operated by the United States National Weather Service and the data are widely and frequently used in SWAT applications (Sexton et al., 2010). The radar data set was very similar to the initial weather station data and this resulted in no change in the simulation outputs. 


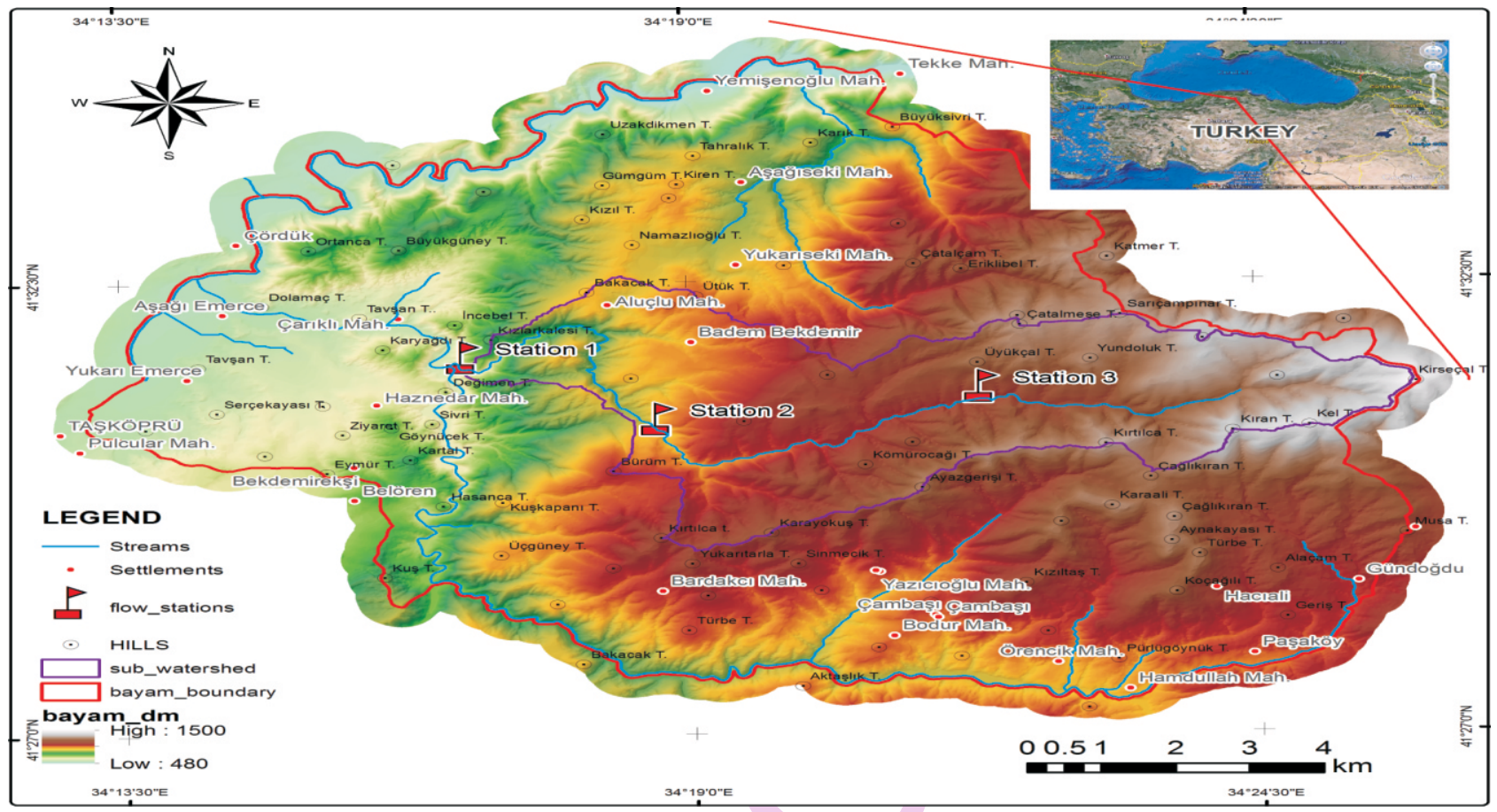

Fig. 1 : The study area, Bayam Forest District. The main stream network are illustrated with a blue line and the locations of three stations for streamflow measurement with red flags on the major stream within the sub-watershed that were used for SWAT calibration

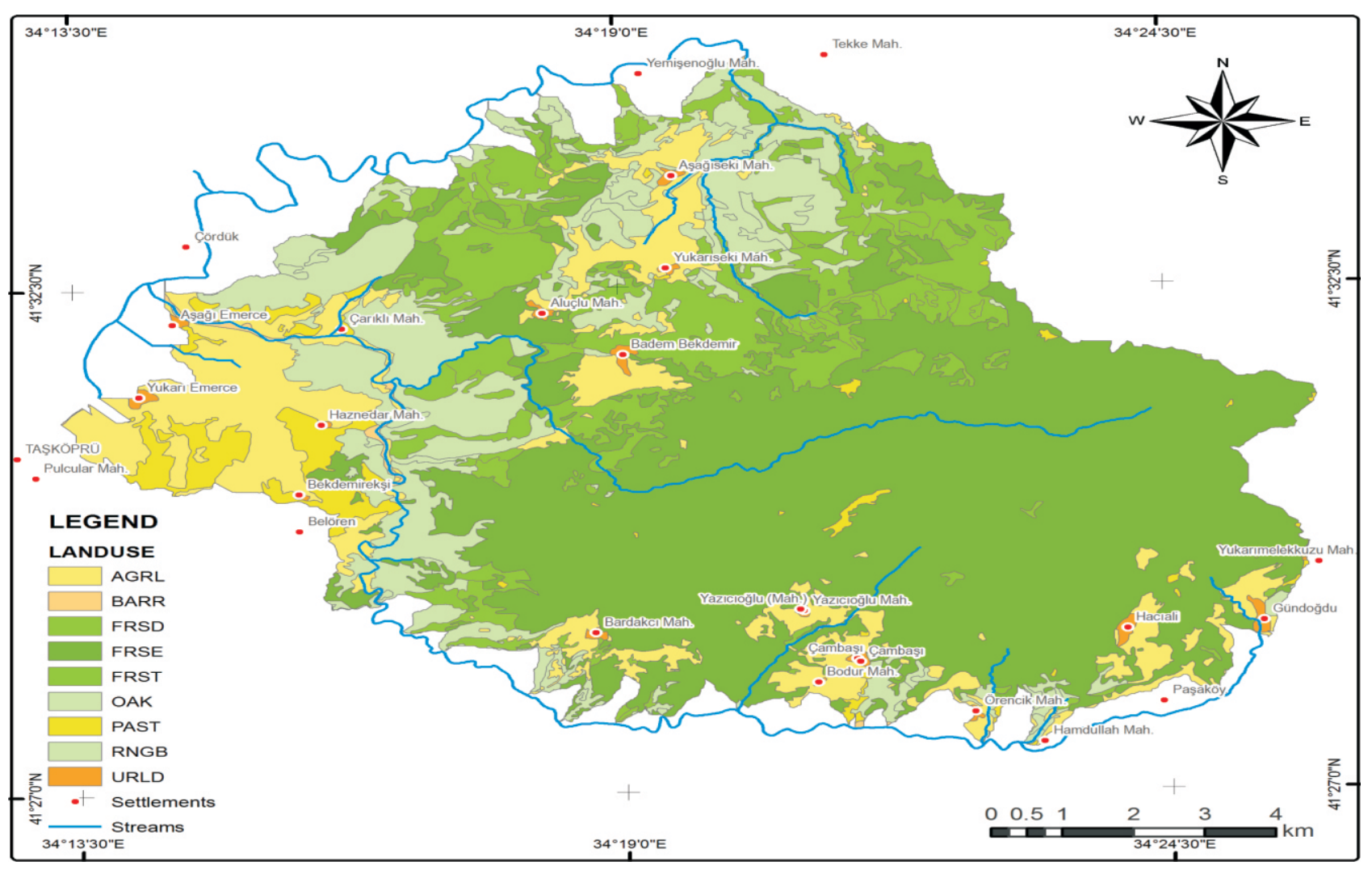

Fig. 2 : The land-use map of Bayam Forest District. The land-use classification/codes used in the SWAT were: OAK: Oak, FRSE: Forest Evergreen, FRSD: Forest Deciduous, BARR: Barren area, RNGB: Shrubland, FRST: Forest Mixed, PAST: Pasture, AGRL: Agricultural land generic, URLD: Urban low density 


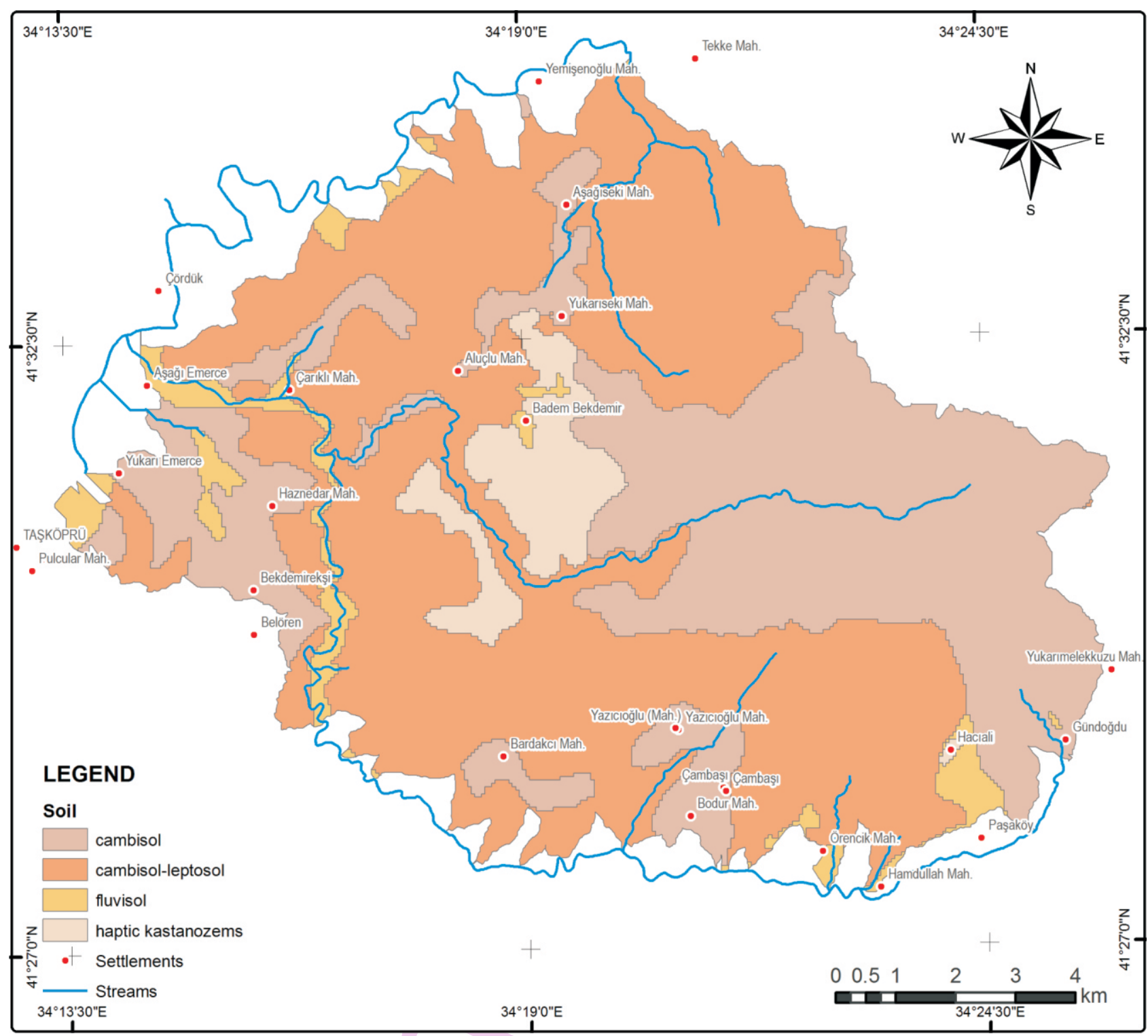

Fig. 3 : The soil map of Bayam Forest District classified under four main soil groups that included (a) cambisol, (b) cambisol-leptosol (c) fluvisol and (d) haptic kastanozems

In the present study, the main reason for the unsuccessful calibration was the over estimation of the simulated discharge by the SWAT model compared to the observed discharge in the flow measurement stations (Fig. 4). A possible explanation for this unsatisfactory calibration could be due to alteration in soil-water storage in response to increasing percolation from soil to aquifer recharge (groundwater processes) that may not be well presented in the model (Me et al., 2015) and in many cases might be infeasible to calibrate (Shen et al., 2012). Another potential reason for unsatisfactory calibration could have been insufficiency in capturing the spatial and temporal variability of rainfall (Bouraoui et al., 2005; Thyer et al., 2009). The study area in Taskopru and the location of the weather station in Kastamonu were about $50 \mathrm{~km}$ apart (although this was the closest weather station to the study area). This resulted in over-prediction of simulated discharges and mismatching of precipitation and responding discharge values that were not observed in the field measurements. Additionally, having worked at a small catchment scale may also contribute to this unsatisfactory calibration (Mengistu and Sorteberg, 2012). A recent study conducted in a small catchment $\left(77 \mathrm{~km}^{2}\right)$ by Me et al. (2015) recorded underestimated simulation values compared to observed values, and emphasized on parameter sensitivity in varying hydrological settings, including both base flow and quick/peak flow conditions to improve the SWAT model performance. 


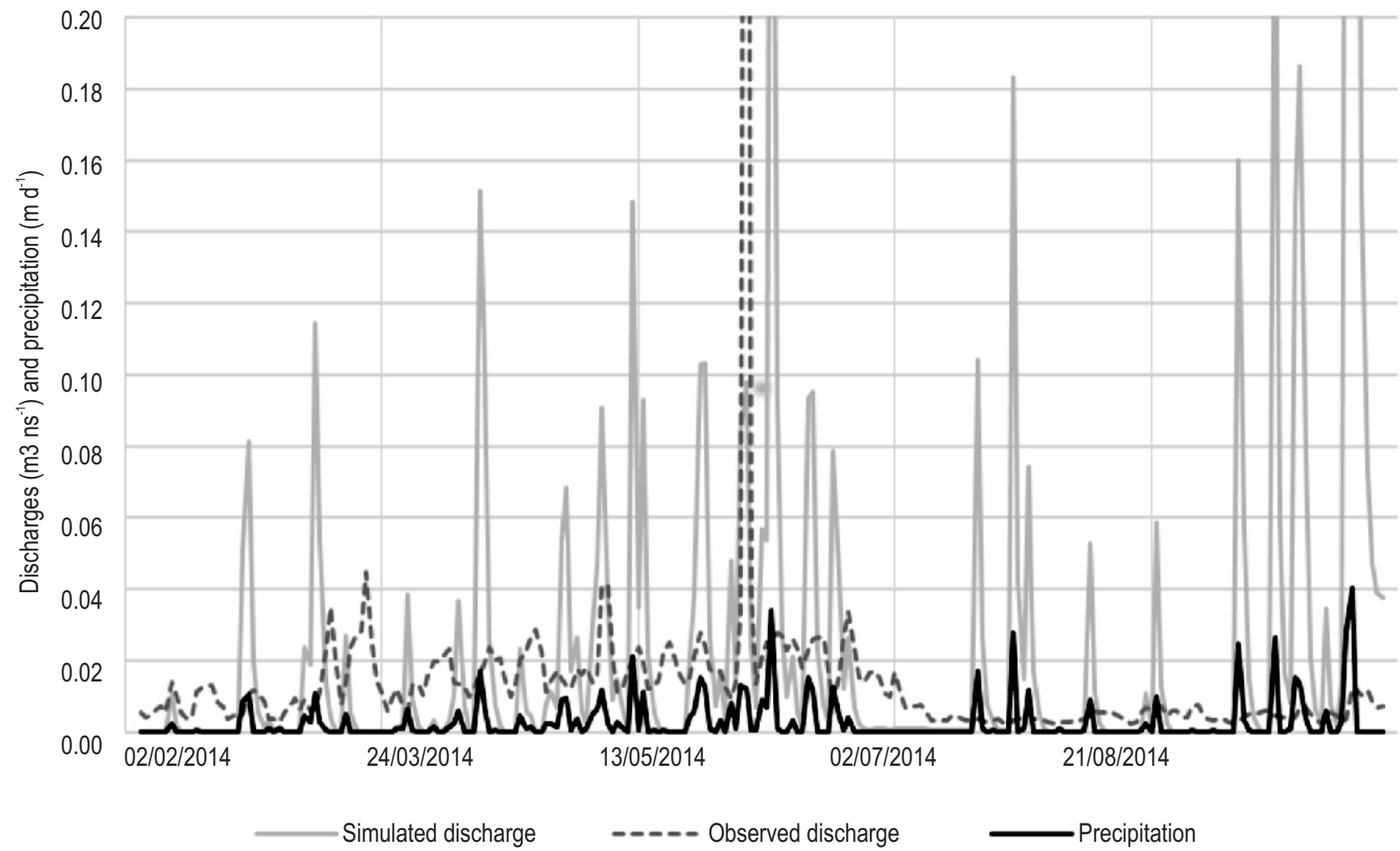

Fig. 4 : The observed and simulated discharge for the Bayam Forest District along with the observed precipitation values

Table 1 : The average simulated water balance phases for the entire study area (Bayam Forest District) and for the major stream where the stream flow measurements were carried on

\begin{tabular}{lll}
\hline Water balance phases & Bayam forest district (mm per yr) & Major stream (mm per yr) \\
\hline Precipitation & 822.0 & 822.0 \\
Snow fall & 107.0 & 107.0 \\
Snow melt & 105.6 & 105.6 \\
Sublimation & 1.40 & 1.46 \\
Surface runoff (SR) & 44.2 & 24.8 \\
Lateral flow (LF) & 110.4 & 100.6 \\
Total aquifer recharge/percolation & 92.1 & 111.4 \\
Groundwater flow to stream (GF) & 80.0 & 97.6 \\
Revap from lateral to soil/plants & 7.50 & 8.23 \\
Deep aquifer recharge & 4.60 & 5.57 \\
Total water yield; SR+LF+GF & 234.6 & 223.0 \\
Evaporation-Transpiration & 573.8 & 583.1 \\
\hline
\end{tabular}

Nevertheless, the hydrological budget simulated by the SWAT model indicated that about $70 \%, 13.4 \%, 9.7 \%$, and $5.4 \%$ of the total precipitation $(822 \mathrm{~mm})$ were yielded from the Bayam Forest District via evapotranspiration, lateral flow, groundwater flow and surface runoff, respectively (Table 1). The simulated average stream discharge $\left(\mathrm{m}^{3} \mathrm{~s}^{-1}\right)$ is depicted in Fig. 5 in order to identify the sub-watersheds with high stream discharges. The classification in the five categories based on the simulated values are as follows: $0.004-0.026,0.027-0.071,0.072-0.152,0.153-$
0.254 and $0.255-0.445 \mathrm{~m}^{3} \mathrm{~s}^{-1}$ (Fig. 5). The blue and dark green sections of the basin, which represent the areas of estimated high discharge, were most suitable locations for the reservoir placement, which also partially coincided with locations of some current reservoirs built by the Forest Service (Fig. 5). This indicates that even with unsatisfactory calibration, the application of SWAT model on the selected area provided a promising benefit on the selection of optimum reservoir locations. The produced spatial streamflow map can be used as a guide to further examine 


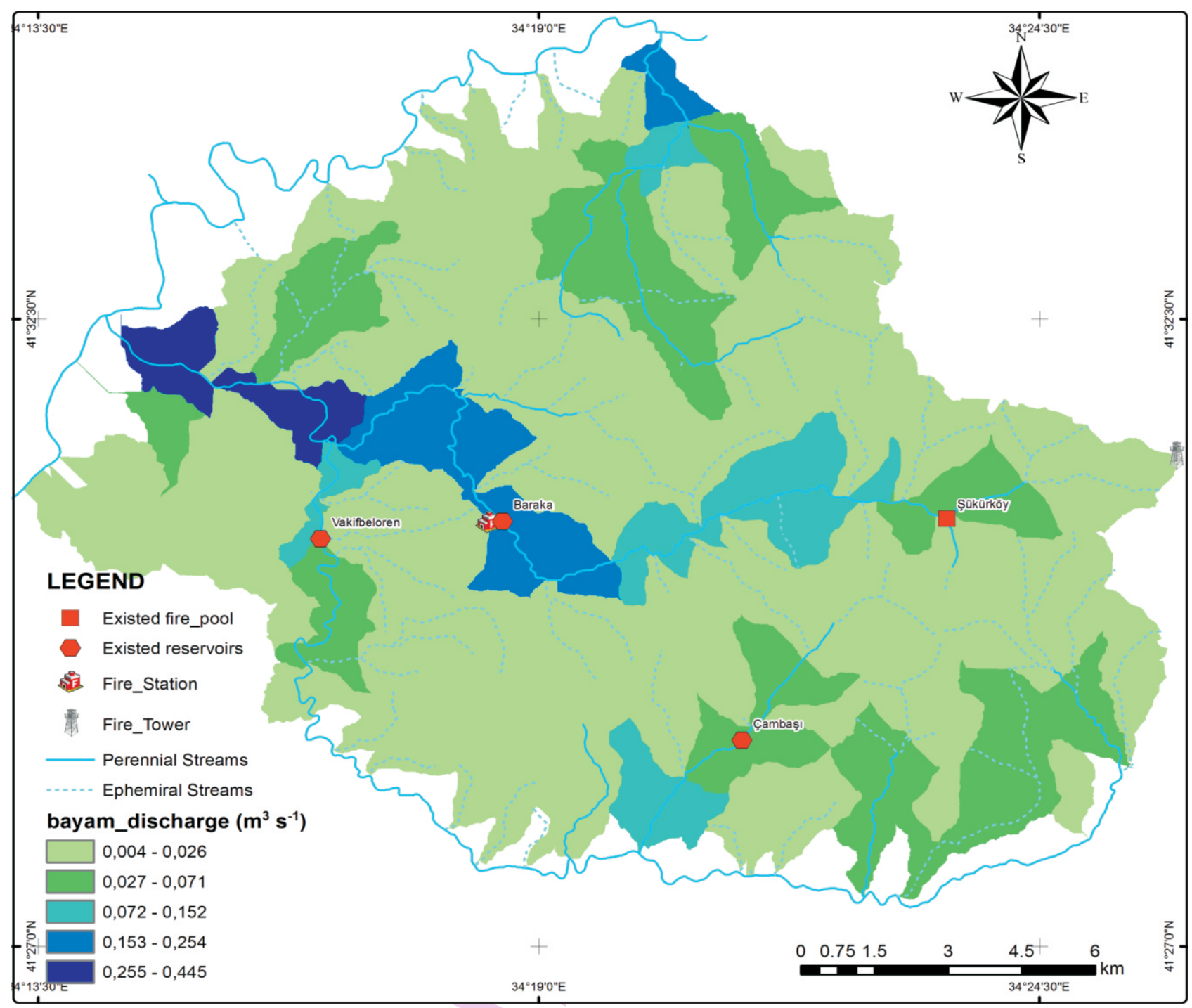

Fig. 5 : The average streamflow during 2014 for the Bayam Forest District. The discharge of the study area were divided in five categories of stream flow. The stream reaches within the bluish and/or dark greenish catchments of the basin had high stream flows/discharges that show the potential reservoirs location to use for wildfire suppression

the hydrologic conditions on prefered locations for water reservoirs in streams. Proper management, collection and storage of water in reservoirs could assist the Forest Service and Fire Departments to suppress future forest wildfires more efficiently in the region.

In conclusion, this study provides a first step for the better management of water resources using the SWAT model to assist water and land managers of the region in locating water reservoirs for suppressing forest wildfire in Turkey.

\section{Acknowledgments}

Authors would like to thank the Central Finance and Contracts Unit (CFCU) in TURKEY and the EU INTERREG IV
"Black Sea Basin Joint Operational Programme 2007-2013" framework that funded this project. In addition, we would like the staff members of the Kastamonu Regional Directorate of Forestry, Yasar Cakiroglu, Muzaffer Buyukterzi and Hidayet Kavi for their generous help and support.

\section{References}

Abbaspour, K.C., J. Yang, I. Maximov, R. Siber, K. Bogner, J. Mieleitner, J. Zobrist and R. Srinivasan: Modelling hydrology and water quality in the pre-alpine/alpine Thur watershed using SWAT. J. Hydrol., 333, 413-430 (2007)

Amiro, B.D., B.J. Stocks, M.E. Alexander, M.D. Flannigan and B.M. Wotton: Fire, climate change, carbon and fuel management in the 
Canadian boreal forest. Int. J. Wildland Fire, 10, 405-413 (2001).

Arnold, J.G., R. Srinivasan, S.R. Muttiah and J.R. Williams: Large area hydrologic modeling and assessment part I. Model development1. J.Am. Water. Res. Assoc., 34, 73-89 (1998).

BCWS: British Colombia Wildfire Service. Wildland fire management strategy (2010). http://bcwildfire.com/Prevention/PrescribedFire/ docs/BCWFMS.pdf.

Bouraoui, F., S. Benabdallah, A. Jrad and G. Bidoglio: Application of the SWAT model on the Medjerda River basin (Tunisia). Physics Chem. Earth, 30, 497-507 (2005).

Brenkert-Smith, H.: Building bridges to fight fire: The role of informal social interactions in six Colorado wildland-urban interface communities. Int. J. Wildland Fire, 19, 689-697 (2010).

Cao, W., W.B. Bowden, T. Davie and A. Fenemor: Multi-variable and multi-site calibration and validation of SWAT in a large mountainous catchment with high spatial variability. Hydrol. Process., 20, 1057-1073 (2006).

Cardil, A., M. Salis, D. Spano, G. Delogu and D.M. Terrén: Large wildland fires and extreme temperatures in sardinia (Italy). IForest., 7, 162169 (2014).

Dalfes, H.N., M. Karaca and Ö.L. Şen: Climate change scenarios for Turkey. In: Climate Change and Turkey: Impacts, sectoral analyses, socio-economic dimensions (Ed: Ç. Güven). Publications of United Nations Development Programme (UNDP) Turkey Branch, Ankara, pp. 11-17 (2007).

Fernandes, P.M.: Fire-smart management of forest landscapes in the mediterranean basin under global change. Lands. Urban Plan., 110, 175-182 (2013).

Gassman, P.W., M.R. Reyes, C.H. Green and J.G. Arnold: The soil water and assessment tool: Historical development, applications and future research directions. Trans. Am. Soci. Agric. Biol. Eng., 50, 1211-1250 (2007).

GDF: Functional forest management plan. Kastamonu General Directorate of Forestry (OGM). In Turkish: Fonksiyonel Orman Amenajman Plani. Kastamonu Orman Bolge Mudurlugu, Taskopru Isletme Mudurlugu, Bayam Isletme Sefligi) (2009).

GDF-DFFF: Report for the forest fighting activities in 2014. General Directory of Forestry- Dep. of Forest Fire Fighting. In Turkish: Orman yanginlari ile mucadele faliyetleri 2014 yili degerlendirme raporu) (2014).

HWSD: Harmonized World Soil Database Viewer., http://webarchive.iiasa.ac.at/Research/LUC/External-World-soildatabase/HTML (2012).

Lyon, L.J., M.H. Huff, R.G. Hooper, E.S. Telfer, D.S. Schreiner and J.K. Smith: Wildland fire in ecosystems effects of fire on fauna. General Technical Report RMRS-GTR-42, Vol. 1, Ogden, UT, USA, p. 83 (2000).

Me, W., J.M. Abell and D.P. Hamilton: Effects of hydrological conditions on SWAT model performance and parameter sensitivity for small, mixed land use catchment in New Zealand. Hydrol. Earth Syst. Sci., 19, 4127-4147 (2015).

Meddour-Sahar, O.: Wildfires in Algeria: Problems and challenges. iForest., 8, 818-826 (2014).

Mengistu, D.T. and A. Sorteberg: Sensitivity of SWAT simulated streamflow to climatic changes within the Eastern Nile River basin. Hydrol. Earth. Syst. Sci., 16, 391-407 (2012).

MFWA: Forest Statistics (2012). Republic of Turkey Ministry of Forestry and Water Affairs. A publication of official statistics programme. Ankara, 3, p. 180. (2014).

Nearing, M.A., G.R. Foster, L.J. Lane and S.C. Finkner:A process-based soil erosion model for USDA-Water Erosion Prediction Project
Technology. Trans. Am. Soci. Agric. Eng., 32, 1587-1593 (1989).

Neary, D.G., K.C. Ryan and L.F. DeBano: Wildland fire in ecosystems: Effects of fire on soils and water; General Technical Report RMRSGTR-42; Department of Agriculture, Forest Service, Rocky Mountain Research Station, Ogden, UT, USA, p. 250 (2005).

Neitsch, S.L., J.G. Arnold, J.R. Kiniry, J.R. Williams and K.W. King: Soil and water assessment tool-theoretical documentation-version 2009. Grassland, Soil and Water Research Laboratory, Agricultural Research Service and Blackland Research Center, Texas Agricultural Experiment Station, Temple, Texas, USA (2011).

Neitsch, S.L., J.G. Arnold, J.R. Kiniry and J.R. Williams: The soil and water assessment tool. Version 2005. http://www.brc. tamus.edu/swat/doc.html (2005).

Nyeko, M.: Hydrologic modelling of data scarce basin with SWAT Model: Capabilities and Limitations. Water Resour. Manage., 29, 81-94 (2015).

Ozturk, M., S. Gucel, M. Kucuk and S. Sakcali: Forest diversity, climate change and forest fires in the Mediterranean region of Turkey. $J$. Environ. Biol., 31, 1-9 (2010).

Rachaniotis, N.P. and C.P. Pappis: Minimizing the total weighted tardiness in wildfire suppression. Operational Res., 11, 113-120 (2011).

Robichaud, P.R.: Fire effects on infiltration rates after prescribed fire in northern Rocky Mountain forests, USA. J. Hydrol., 231-232, 220229 (2000).

Sexton, A.M., A.M. Sadeghi, X. Zhang, R. Srinivasan and A. Shirmohammadi: Using NEXRAD and rain gauge precipitation data for hydrologic of SWAT in a northeastern watershed. Trans. Am. Soci. Agric. Biol. Eng., 53, 1501-1510 (2010).

Shen, Z.Y., L. Chen and T. Chen: Analysis of parameter uncertainty in hydrological and sediment modeling using GLUE method: A case study of SWAT model applied to Three Gorges Reservoir Region, China. Hydrol. Earth Syst. Sci., 16, 121-132 (2012).

TGHB: General Directorate of Agricultural Reform. In Turkish: Tarım Reformu Genel Müdürlüğü Türkiye Büyük Toprak Grubu Veri Tabanı Bilgileri) (2014).

Thyer, M., B. Renard, D. Kavetski, G. Kuczera, S.W. Franks and S. Srikanthan: Critical evaluation of parameter consistency and predictive uncertainty in hydrological modeling: a case study using Bayesian total error analysis. Water Resour. Res., 45 (2009).

Tufekcioglu, A., M. Kucuk, B. Saglam, E. Bilgili and L. Altun: Soil properties and root biomass responses to prescribed burning in young corsican pine (Pinus nigra Arn.) stands. J. Environ. Biol., 31, 369-373 (2010a).

Tufekcioglu, A., M. Kucuk, T. Bilmis, L. Altun and M. Yilmaz: Soil respiration and root biomass responses to burning in Calabrian pine (Pinus brutia) stands in Edirne, Turkey. J. Environ. Biol., 31, 15-19(2010b).

Winchell, M., R. Srinivasan, M. Ri-Luzio and J.G. Arnold: ArcSWAT Interface for SWAT 2009: User's Guide. Texas Agricultural Experiment Station and USDA Agricultural Research Service, Temple, Texas, USA(2013).

Yildiz, O., D. Esen, M. Sarginci and B. Toprak: Effects of forest fire on soil nutrients in Turkish pine (Pinus brutia, Ten) ecosystem. J. Environ. Biol., 31, 11-13 (2010).

Zaimes, N.G., M. Tufekcioglu, S. Zibtsev, M. Yavuz, D. Emmanouloudis, D. Kaziolas, R. Corobov, R. Uratu, A. Ghulijanyan, A. Borsuk and I. Tronbitsky: Developing a holistic and complete approach for wildfire suppression for the Black Sea Region. In conference proceedings of the International Forest Fire Conference in Black Sea Region, Kastamonu, Turkey, pp. 9-18(2014). 